\title{
Summer Cultivation Increases Field Infiltration Rates of Water and Reduces Soil Electrical Conductivity on Annual Bluegrass Golf Greens
}

\author{
Robert L. Green ${ }^{1}$ \\ Department of Botany and Plant Sciences, University of California, Riverside, \\ CA 92521-0124
}

Laosheng Wu

Department of Environmental Sciences, University of California, Riverside, CA 92521-0124

\section{Grant J. Klein}

Department of Botany and Plant Sciences, University of California, Riverside, CA 92521-0124

Additional index words. leaching of soil salts, Poa annua, rooting, soil oxygen diffusion rate, soil porosity, solid tine cultivation, water injection cultivation

\begin{abstract}
Summer decline of annual bluegrass (Poa annua L.) putting greens is a major concern of golf course superintendents. Low soil water infiltration rates and high concentrations of salts in the root zone are contributing factors. This study was conducted to determine the effects of summer cultivation treatments on field infiltration rates of water, soil salinity, oxygen diffusion rates (ODR), bulk density, total and air-filled porosity, and root weight density. This research was conducted during two summer seasons (1996 and 1997) on a practice putting green located at Industry Hills Golf Courses, City of Industry, Calif. The green was constructed to U.S. Golf Association (USGA) specifications in 1978. Cultivation treatments consisted of: 1-3) water injection cultivation (WIC) applied with a Toro HydroJect every 21 d (raised position), and every 14 or 21 d (lowered position); 4) solid tine cultivation (STC) applied every $14 \mathrm{~d}$; and 5) no cultivation (check). Results showed WIC and STC significantly increased field infiltration rates of water and lowered overall soil electrical conductivity of the extract $\left(\mathrm{EC}_{\mathrm{e}}\right)$ at depths of 2.5 to $7.5 \mathrm{~cm}$ and 7.5 to $15.0 \mathrm{~cm}$ in the root zone. The effects of WIC, raised position, did not differ significantly from those of STC, but infiltration rates of water were greater on all rating dates. Cultivation treatments had no significant effects on overall soil ODR, bulk density, and porosity or on overall root weight density.
\end{abstract}

Summer decline of annual bluegrass putting greens is a major concern of golf course superintendents in southern California and in other regions of the United States. The decline is associated with the stresses due to heat, surface soil compaction, excess or lack of soil water, lack of soil aeration, excess of soil salinity, traffic, pests, and other factors. Though the successful management of annual bluegrass putting greens involves numerous aspects of the annual cultural program (Carrow

Received for publication 23 Dec. 1999. Accepted for publication 14 Aug. 2000. We thank Bert Spivey and Kent Davidson, golf course superintendents at Industry Hills Golf Courses, City of Industry, Calif., for their invaluable assistance with field plot maintenance and research activity support. We also thank Francisco Merino and Ralph Strohman for their technical support throughout the course of this study. The cost of publishing this paper was defrayed in part by the payment of page charges. Under postal regulations, this paper therefore must be hereby marked advertisement solely to indicate this fact.

${ }^{1}$ To whom reprint requests should be addressed. E-mail address: robert.green@ucr.edu and Duncan, 1998), summer cultivation helps to mitigate the effects of several factors associated with summer decline.

Summer cultivation of putting greens is effective for reducing surface soil compaction and hardness due to increased summer traffic, maintaining soil water infiltration and percolation, and maintaining soil porosity (Murphy and Rieke, 1994). When a soil is irrigated with highly saline water [i.e., electrical conductivity $(\mathrm{EC}) \geq 1.5 \mathrm{dS} \cdot \mathrm{m}^{-1}$ ], turfgrasses sensitive to salt are more susceptible to high temperature stress (Carrow and Duncan, 1998). Compacted soils with limited soil water infiltration and percolation, limited gas exchange, and high concentrations of salts probably exacerbate the detrimental effects of prolonged high temperatures. Maintenance of good soil physical characteristics is one key for successfully maintaining quality annual bluegrass putting greens during the summer.

Carrow and Petrovic (1992), Carrow and Wiecko (1989), and Rieke and Murphy (1989) have reviewed soil compaction, wear stresses, and turfgrass cultivation methods. Mainte- nance of proper soil physical characteristics often includes soil cultivation during the spring, fall, or both, with wide-diameter tines, drills, or both, followed by topdressing. This may be the most important step for reducing summer decline of annual bluegrass putting greens and is a part of a long term program for increasing soil water infiltration rates and soil aeration porosity. However, the focus of this research was on soil cultivation during the summer, when growing conditions were not optimal for annual bluegrass. Because of increases in traffic and environmental stress during the summer, less disruptive and stressful techniques of soil cultivation are practiced. These techniques include spiking and coring with relatively narrow-diameter solid tines, or a recently developed technique involving high-pressure water injection cultivation (WIC) with a Toro HydroJect (The Toro Co., Minneapolis) or similar equipment. The WIC technique uses short bursts of high velocity streams of water to cultivate the soil while minimizing surface disruption. Murphy and Rieke (1994) evaluated the response of 'Penncross' creeping bentgrass (Agrostis palustris Huds.) growing on a modified loamy sand to both WIC and hollow tine cultivation (HTC). Cultivation treatments were applied three and two times in 1988 and 1989, respectively, on an experimental putting green compacted periodically with rollers $(50 \mathrm{kPa})$. They found that WIC was equal or superior to HTC in reducing soil bulk density and increasing porosity and saturated hydraulic conductivity in the 0- to 76-mm depth zone. Murphy and Rieke also noted, based on soil penetration resistance data, that WIC provided a significant loosening of the soil to the $100-\mathrm{mm}$ soil depth while the HTC influence was limited to the $60-\mathrm{mm}$ depth. The WIC was not as disruptive as HTC (i.e., it loosened the soil less) in the surface $30 \mathrm{~mm}$. The HTC also reduced the root system considerably more than did WIC, especially at the depths of 0 to $50 \mathrm{~mm}$. Murphy and Rieke concluded that WIC offers the potential for routine cultivation of turfgrass during periods of high site usage and environmental stresses without reducing visual quality.

How well a summer cultivation program will improve soil characteristics and root weight density of an in-use putting green at a golf course is not known. This two-season study was conducted to test the effects of solid tine cultivation (STC) and WIC treatments on field infiltration rates of water, soil salinity, oxygen diffusion rates (ODR), bulk density, total and air-filled porosity, and root weight density.

\section{Materials and Methods}

The mature, in-use annual bluegrass practice putting green was grown on a modified root-zone soil $(89 \%$ sand, $7 \%$ silt, and $4 \%$ clay), constructed to USGA specifications at Industry Hills Golf Courses, City of Industry, Calif., and seeded to 'Penncross' creeping bentgrass in 1978. As normally happens in southern California, the green naturally converted to a native annual bluegrass. A visual 
estimate at the beginning of the study indicated that the putting green was composed of $\approx 80 \%$ annual bluegrass and $20 \%$ creeping bentgrass.

Cultivation treatments were applied from 18 July to 18 Nov. 1996 and from 19 May to 22 Sept. 1997. The treatments were arranged in a randomized complete-block design with four replications. Plot size was $1.83 \times 6.10 \mathrm{~m}$. The treatments consisted of: 1-3) WIC applied every $21 \mathrm{~d}$ with a Toro HydroJect in the raised position, and applied either every 14 or $21 \mathrm{~d}$ with the same equipment in the lowered position; 4) STC applied every $14 \mathrm{~d}$; and 5) no cultivation (check). The STC treatment was performed with a Toro greens aerifer (model 09100) equipped with 6-mm-diameter $\times 89$ $\mathrm{mm}$-long solid tines producing a hole spacing of $64 \times 64 \mathrm{~mm}$. Holes created by the STC treatment were $\approx 6 \mathrm{~mm}$ in diameter $\times 83 \mathrm{~mm}$ deep. The WIC treatments were performed with a Toro HydroJect 3000, with 11 nozzles (orifice of $1.5 \mathrm{~mm}$ i.d.) spaced $76 \mathrm{~mm}$ apart. When operated in the raised and lowered position, the HydroJect produced a hole spacing of $76 \times 76 \mathrm{~mm}$ and $44 \times 76 \mathrm{~mm}$, respectively. Holes created by the WIC treatment in the raised and lowered position were $\approx 3 \mathrm{~mm}$ diameter $\times 108 \mathrm{~mm}$ deep and $\approx 1.5 \mathrm{~mm}$ diameter $\times 83 \mathrm{~mm}$ deep, respectively. Unlike the other cultivation treatments, the WIC treatment in the raised position created a surface entry ( $\approx 9 \mathrm{~mm}$ in diameter) that was wider than the hole.

The putting green was managed to satisfy the requirements of an in-use practice putting green located on a public golf course that annually receives $\approx 70,000$ rounds of play. The green was maintained at a 4- to 5-mm cutting height, with the higher cutting heights utilized during the summer to reduce high-temperature stress. The green was irrigated to prevent visual drought symptoms and to provide the most satisfactory putting surface. The irrigation water source was effluent with an EC $\approx 0.98 \mathrm{dS} \cdot \mathrm{m}^{-1}$. Leaching of excess salts was performed by applying $\approx 36 \mathrm{~mm}$ of irrigation on the last Sunday of each month during the period when cultivation treatments were applied. To maintain adequate turfgrass growth and color, $\mathrm{N}$ was applied at an annual rate of $488 \mathrm{~kg} \cdot \mathrm{ha}^{-1}$ using a combination of ammonium, urea, and nitrate $\mathrm{N}$ sources. Annual applications of $\left(\mathrm{NH}_{4}\right)_{2} \mathrm{HPO}_{4}, \mathrm{~K}_{2} \mathrm{SO}_{4}$, and $\mathrm{FeSO}_{4}$ were made to supply 117,610 , and $36 \mathrm{~kg} \cdot \mathrm{ha}^{-1}$ of $\mathrm{P}, \mathrm{K}$, and $\mathrm{Fe}$, respectively. Fungicides were applied to prevent or control various summer diseases.

Field infiltration rates of water were measured during 2 consecutive days, twice in 1996 and three times in 1997 (see Table 1 for dates). On each of the $2 \mathrm{~d}$, two complete blocks were measured. Measurements were taken after a date in which all cultivation treatments were applied ( 8 to $11 \mathrm{~d}$ and 8 to $9 \mathrm{~d}$ after cultivation, in 1996 and 1997, respectively). Also, measurements were normally taken $1 \mathrm{~d}$ after irrigation. On each date, two measurements were taken from the north $1.83 \times 2.44 \mathrm{~m}$ end of each plot with a double-ring infiltrometer with a 20 -cm inner ring, 30-cm outer ring, and a 5.0$\mathrm{cm}$ ponding depth. Steady-state infiltration rate was obtained when readings in the inner ring approached a constant rate ( $\mathrm{Wu}$ et al., 1997). The two measurements from each plot were averaged. Infiltration rate data were not normally distributed based on the ShapiroWilk test (Shapiro and Wilk, 1965). Therefore, these data were transformed using the common log, and subjected to analysis of variance (ANOVA), including a contrast and a mean separation procedure, and treatment means were back-transformed to the antilog $\left(10^{\times}\right.$, where $x=$ mean in the common log scale).

The ODR was measured on the same dates as field infiltration rates of water plus an additional date on 16 Oct. 1996 (90 d after initial cultivation treatments and $9 \mathrm{~d}$ after a date in which all cultivation treatments were applied). The measurements followed the procedures of Phene (1986). Eight platinum microelectrodes were used to measure ODR for each plot at a depth of $2.5 \mathrm{~cm}(\approx 1.0 \mathrm{~cm}$ below the soil-thatch line) with a soil ODR meter (Jensen Instruments, Tacoma, Wash.).

Measurements of the soil electrical conductivity of the extract $\left(\mathrm{EC}_{\mathrm{e}}\right)$ were taken as a sample set, each consisting of measurements before and after a leaching event (see Table 2 for leaching event dates). Measurements were normally $2 \mathrm{~d}$ before or after a leaching event. On each measurement date, five 2-cm-diameter cores were taken from the south $1.83 \times$ $3.66 \mathrm{~m}$ end of each plot. A grid was used when taking cores for soil $\mathrm{EC}_{\mathrm{e}}$, soil bulk density and porosity, and root weight density so that a $10 \times 10-\mathrm{cm}$ area was sampled only once over the course of the two-season study. The cores were separated into sections 0 to $2.5,2.5$ to 7.5 , and 7.5 to $15.0 \mathrm{~cm}$ below the soil-thatch line ( $\approx 1.5 \mathrm{~cm}$ below the surface), and sections for each plot were pooled by depth. A 10.0-g soil subsample was placed into a plastic cup and distilled water was added until a saturated soil paste was obtained. A solution from the paste was vacuum extracted and measured for $\mathrm{EC}_{\mathrm{e}}$ using a GLA M33.1 Instant EC Salinity Tester (GLA Agricultural Electronics, 1995).

Soil bulk density and porosity were measured 26 Nov. 1996 and 1 Oct. 1997 (134 and $135 \mathrm{~d}$ after initial cultivation treatments, respectively). Measurements were taken after a cultivation date on which all cultivation treatments were applied. They were taken 8 and 9 d after cultivation in 1996 and 1997, respectively. One undisturbed soil core, $5.0 \mathrm{~cm}$ diameter $\times 5.0 \mathrm{~cm}$ deep (with the $0 \mathrm{~cm}$ depth at the soil-thatch line), was taken from the south $1.83 \times 3.66-\mathrm{m}$ end of each plot. Soil water content at saturation, -10 and $-100 \mathrm{kPa}$ (Klute, 1986), and bulk density were determined from the undisturbed cores. Total and air-filled soil porosity were calculated from these measurements. The volumetric water content at -10 $\mathrm{kPa}$ was assumed to be field capacity for the modified root-zone soil (Cassel and Nielsen, 1986).

Root weight density was measured 26 Sept. and 26 Nov. 1996 (70 and $131 \mathrm{~d}$ after initial treatments, respectively) and on 30 Sept. 1997 (134 d after initial cultivation treatments). Four 3.0-cm-diameter cores were taken from the south $1.83 \times 3.66-\mathrm{m}$ end of each plot. The cores were separated into two sections 0 to 7.5 and 7.5 to $15.0 \mathrm{~cm}$ below the soil-thatch line $(\approx 1.5 \mathrm{~cm}$ below the surface). Cores from each

Table 1. The influence of water injection cultivation (WIC) and solid tine cultivation (STC) treatments on the field infiltration rate of water in an annual bluegrass putting green during 1996 and 1997.

\begin{tabular}{|c|c|c|c|c|c|c|c|}
\hline \multirow[b]{2}{*}{$\begin{array}{l}\text { Cultivation } \\
\text { treatment }\end{array}$} & \multirow[b]{2}{*}{$\begin{array}{c}\text { Application } \\
\text { interval }^{z}\end{array}$} & \multicolumn{2}{|c|}{1996} & \multicolumn{3}{|c|}{1997} & \multirow[b]{2}{*}{ Overall } \\
\hline & & $\begin{array}{l}\text { 5-6 Sept. } \\
(49-50)^{\mathrm{y}}\end{array}$ & $\begin{array}{c}26-27 \text { Nov. } \\
(131-132)\end{array}$ & $\begin{array}{c}\text { 10-11 July } \\
(52-53)\end{array}$ & $\begin{array}{c}\text { 20-21 Aug. } \\
\text { (93-94) }\end{array}$ & $\begin{array}{l}30 \text { Sept. }-1 \text { Oct. } \\
(134-135)\end{array}$ & \\
\hline & $--\mathrm{d}--$ & ---- & ----- & $--\mathrm{cm} \cdot \mathrm{h}^{-1}$ & ----- & ------ & ---- \\
\hline \multicolumn{8}{|l|}{ WIC } \\
\hline Raised position & 21 & 19.7 & 5.6 & $21.0 \mathrm{a}^{\mathrm{x}}$ & $27.2 \mathrm{a}$ & $20.9 \mathrm{a}$ & 16.8 \\
\hline Lowered position & 14 & 5.1 & 1.6 & $5.1 \mathrm{bc}$ & $8.2 \mathrm{bc}$ & $8.3 \mathrm{a}$ & 4.9 \\
\hline Lowered position & 21 & 8.4 & 2.4 & $5.8 \mathrm{abc}$ & $15.0 \mathrm{ab}$ & $12.6 \mathrm{a}$ & 7.4 \\
\hline STC & 14 & 16.5 & 2.3 & $14.8 \mathrm{ab}$ & $16.9 \mathrm{ab}$ & $7.8 \mathrm{a}$ & 9.4 \\
\hline Check & --- & 3.9 & 10.3 & $3.1 \mathrm{c}$ & $4.2 \mathrm{c}$ & $2.4 \mathrm{~b}$ & 4.2 \\
\hline \multicolumn{8}{|l|}{ ANOVA effect and contrast $(\mathrm{P})$} \\
\hline Cultivation treatment $(\mathrm{T})$ & & 0.073 & 0.236 & 0.053 & 0.036 & 0.009 & 0.087 \\
\hline Contrast, WIC and STC vs. check & & 0.052 & 0.066 & 0.038 & 0.010 & 0.001 & 0.077 \\
\hline Date (D) & & & & & & & 0.00 \\
\hline $\mathrm{T} \times \mathrm{D}$ & & & & & & & 0.015 \\
\hline
\end{tabular}

${ }^{z}$ Total number of seasonal applications were ten and seven for treatments applied every 14 and $21 \mathrm{~d}$, respectively.

${ }^{\mathrm{y}}$ No. days after initial cultivation treatments.

${ }^{x}$ Mean separation within columns by Fisher's protected LSD test, $P=0.05$. Statistical analysis based on log transformed data. 
Table 2. Main effects of water injection cultivation (WIC) and solid tine cultivation (STC) treatments, sample set, leaching, and their interactions on overall soil $\mathrm{EC}_{\mathrm{e}}$ at three root-zone depths in an annual bluegrass putting green during 1996 and 1997.

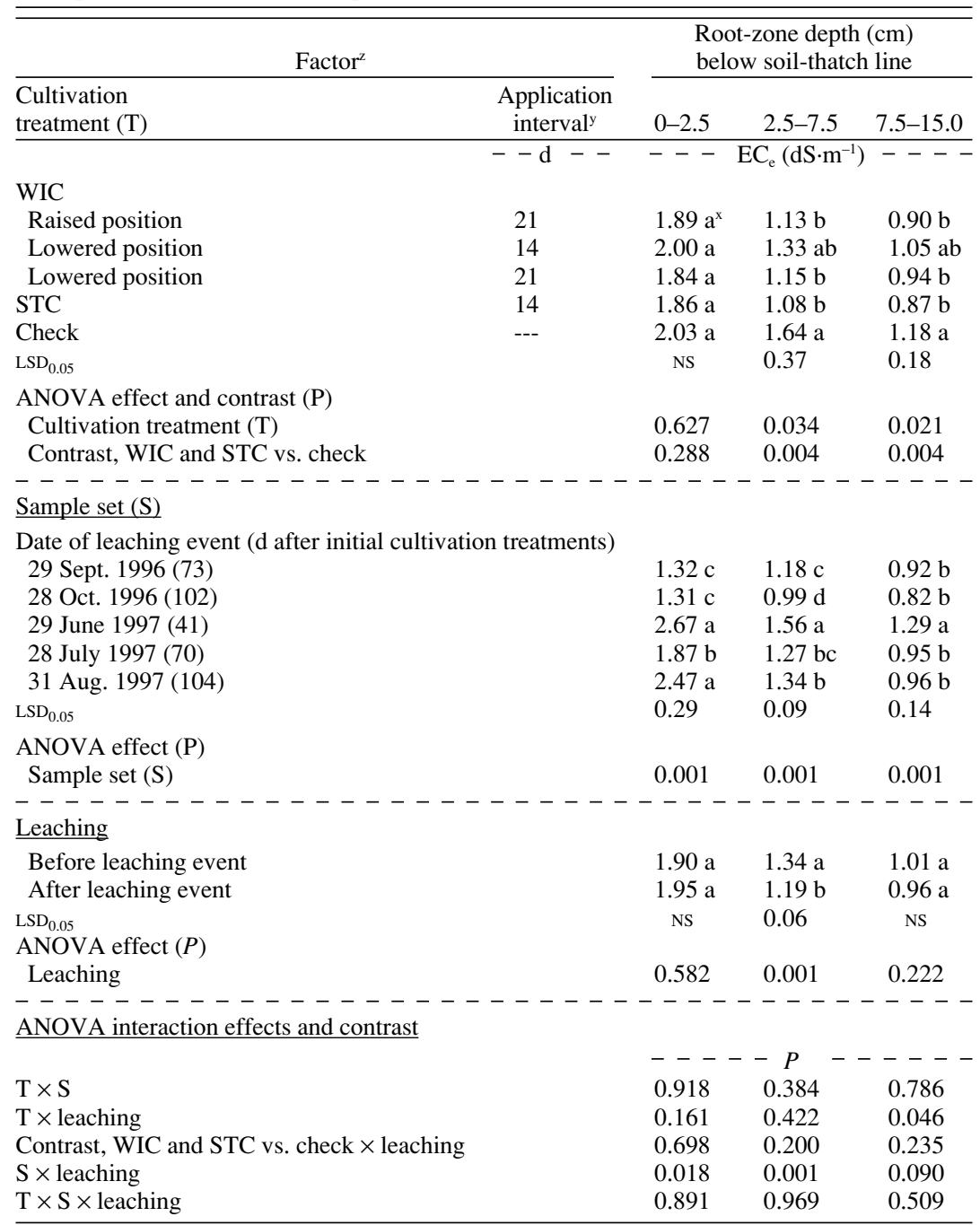

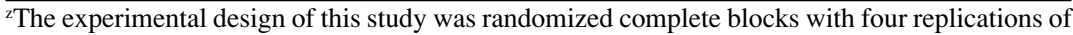
each cultivation treatment. Measurements of soil $\mathrm{EC}_{\mathrm{e}}$ were taken as a sample set $(\mathrm{S})$, each consisting of measurements before and after a leaching event (leaching). The overall ANOVA (by each rootzone depth) was a repeated measures design with $\mathrm{S}$ and leaching as the repeated measures factors. yTotal number seasonal applications were 10 and seven for treatments applied every 14 and $21 \mathrm{~d}$, respectively.

${ }^{x}$ Mean separation within factors and columns by a Fisher's protected LSD test, $P=0.05$.

plot were pooled by root-zone depth, sealed in Ziploc $^{\circledR}$ (Dow Brands L.P., Indianapolis, Ind.) bags, and frozen $\left(-24^{\circ} \mathrm{C}\right)$. After thawing the samples, soil was removed from the roots by washing over a screen. Roots were weighed after drying for $48 \mathrm{~h}$ in a forced-air oven maintained at $60{ }^{\circ} \mathrm{C}$. Data for individual rootzone depths are expressed on a root weight per soil volume basis $\left(\mathrm{kg} \cdot \mathrm{m}^{-3}\right)$.

The experimental design was a randomized complete block with four replications of each of the four cultivation methods and of an untreated check. A repeated measures design was used to analyze the data for field infiltration rate of water, ODR, bulk density, and total and air-filled porosity with date as the repeated measures factor. Also, a repeated measure design was used to analyze the data at each individual soil depth for root weight density, with date as the repeated measures factor, and for soil $\mathrm{EC}_{e}$, with sample sets (S) and measurements before and after a leaching event (leaching) as the repeated measures factors. A general linear model ANOVA was used to test main effects and interactions. Means were compared by using a Fisher's protected LSD test. A contrast was used to test WIC and STC vs. check. For soil EC $\mathrm{e}_{\mathrm{e}}$, emphasis in the analysis was placed on the cultivation treatments (T), leaching, and interaction of $\mathrm{T}$ $\times$ leaching. Thus, an additional contrast, WIC and STC vs. check $\times$ leaching, was used. Interactions, other than that for $\mathrm{T} \times$ leaching, were not considered to be important for the objectives of this study. Therefore, if significant, they were discussed only if they affected the overall conclusions.

\section{Results and Discussion}

Field infiltration rates of water were significantly (one $P=0.052$, all others $<0.050$ ) increased by WIC and STC treatments on each measurement date, with the exception of 2627 Nov. 1996 (Table 1, see contrast, WIC and STC vs. check). Murphy and Rieke (1994) reported that WIC significantly increased saturated hydraulic conductivity during the second year of a 2-year study. The effect of WIC in the raised position did not differ significantly from that of STC, although it was greater on all measurement dates. This treatment created the fewest holes per unit area, but provided the widest-diameter surface entry into the holes. The latter characteristic may have increased field infiltration rates of water by causing holes to remain open for a longer period of time.

The $\mathrm{EC}_{\mathrm{e}}$ of the soil was measured as five sample sets (S) each consisting of measurements before and after a leaching event (leaching). An overall analysis of soil $\mathrm{EC}_{\mathrm{e}}$ for each root-zone depth consisted of a repeated measures design with $\mathrm{S}$ and leaching as the factors (Table 2). This method of analysis was used because emphasis was placed on cultivation treatments $(\mathrm{T})$, leaching, and $\mathrm{T} \times$ leaching, and because the interactions and contrast of $\mathrm{T} \times \mathrm{S}$, $\mathrm{T} \times$ leaching, $\mathrm{T} \times \mathrm{S} \times$ leaching, and WIC and STC vs. check $\times$ leaching were generally nonsignificant.

The WIC and STC treatments significantly decreased overall soil $\mathrm{EC}_{\mathrm{e}}$ at depths of 2.5 to $7.5 \mathrm{~cm}$ and 7.5 to $15.0 \mathrm{~cm}(P=0.004$ in each case) but not of 0 to $2.5 \mathrm{~cm}$ (Table 2, see contrast, WIC and STC vs. check). The lack of salt leaching at shallow depth was probably due to the higher organic matter content and cation exchange capacity. Thus, less leaching occurred in the top layer than in the coarsertextured subsurface sand. No differences in soil $\mathrm{EC}_{\mathrm{e}}$ levels among WIC and STC treatments were significant, regardless of rootzone depth.

Sample set $(\mathrm{S})$ and $\mathrm{S} \times$ leaching were generally significant, which may suggest the dynamic nature of soil salinity during the two seasons. The overall leaching effect was only significant at the 2.5-to 7.5 -cm depth. Leaching had a minimal effect, probably because of the relatively low salinity in the irrigation water and in the 0 - to $15-\mathrm{cm}$ root zone below the soil thatch line $(\approx 1.5 \mathrm{~cm}$ below the surface).

Measurements of ODR were normally taken $1 \mathrm{~d}$ after an irrigation. Overall ODR values (Table 3 ) were higher than the critical value of 0.2 to $0.3 \mu \mathrm{g} \mathrm{O} \cdot \mathrm{cm}^{-2} \cdot \mathrm{min}^{-1}$, and therefore sufficient (Stolzy and Letey, 1964). There were no significant differences in overall ODR among cultivation treatments.

The WIC and STC treatments did not significantly affect overall soil bulk density or total and air-filled porosity (Table 3 ). Murphy and Rieke (1994) reported that WIC and HTC (13-mm-diameter hollow tines) significantly lowered soil bulk density and increased airfilled porosity and total porosity in the 0 to 76 $\mathrm{mm}$ depth of a creeping bentgrass putting green. One explanation as to why the results of our study differ from those of Murphy and Rieke is that their study site had a higher soil bulk density and a lower soil porosity, which made their improvement more likely. In our 
Table 3. The influence of water injection cultivation (WIC) and solid tine cultivation (STC) treatments on overall soil oxygen diffusion rate, total and air-filled porosity, and bulk density; and overall root weight density in an annual bluegrass putting green during 1996 and 1997.

\begin{tabular}{|c|c|c|c|c|c|c|c|}
\hline \multirow{4}{*}{$\begin{array}{l}\text { Cultivation } \\
\text { treatment }\end{array}$} & \multirow{4}{*}{$\begin{array}{c}\text { Application } \\
\text { interval }^{\mathrm{z}}\end{array}$} & \multirow{2}{*}{$\begin{array}{c}\text { Overall oxygen } \\
\text { diffusion rate }\end{array}$} & \multirow{2}{*}{$\begin{array}{c}\text { Overall } \\
\text { bulk density }\end{array}$} & \multicolumn{2}{|c|}{ Overall porosity } & \multirow{2}{*}{\multicolumn{2}{|c|}{$\begin{array}{c}\text { Overall root } \\
\text { wt density }\end{array}$}} \\
\hline & & & & Total & Air-filled & & \\
\hline & & \multicolumn{6}{|c|}{ Root-zone depth below soil-thatch line $(\mathrm{cm})$} \\
\hline & & 1.0 & $0-5.0$ & $0-5.0$ & $0-5.0$ & $0-7.5$ & $7.5-15.0$ \\
\hline \multicolumn{8}{|c|}{ Holata } \\
\hline Raised position & 21 & $0.59 \mathrm{a}^{\mathrm{y}}$ & $1.44 \mathrm{a}$ & $0.457 \mathrm{a}$ & $0.236 \mathrm{a}$ & $0.803 \mathrm{a}$ & $0.029 \mathrm{a}$ \\
\hline Lowered position & 14 & $0.54 \mathrm{a}$ & $1.42 \mathrm{a}$ & $0.464 \mathrm{a}$ & $0.227 \mathrm{a}$ & $0.750 \mathrm{a}$ & $0.019 \mathrm{a}$ \\
\hline Lowered position & 21 & $0.60 \mathrm{a}$ & $1.44 \mathrm{a}$ & $0.456 \mathrm{a}$ & $0.253 \mathrm{a}$ & $0.934 \mathrm{a}$ & $0.027 \mathrm{a}$ \\
\hline STC & 14 & $0.60 \mathrm{a}$ & $1.45 \mathrm{a}$ & $0.453 \mathrm{a}$ & $0.253 \mathrm{a}$ & $0.750 \mathrm{a}$ & $0.022 \mathrm{a}$ \\
\hline Check & --- & $0.51 \mathrm{a}$ & $1.42 \mathrm{a}$ & $0.462 \mathrm{a}$ & $0.221 \mathrm{a}$ & $0.764 \mathrm{a}$ & $0.015 \mathrm{a}$ \\
\hline $\mathrm{LSD}_{0.05}$ & & NS & NS & NS & NS & NS & NS \\
\hline ANOVA effects and contrast & & ------ & ---- & ---- & ---- & ---- & ---- \\
\hline Cultivation (T) & & 0.251 & 0.899 & 0.899 & 0.388 & 0.945 & 0.474 \\
\hline Contrast, WIC and STC vs. check & & 0.067 & 0.655 & 0.655 & 0.193 & 0.785 & 0.134 \\
\hline Date (D) & & 0.001 & 0.001 & 0.001 & 0.137 & 0.001 & 0.378 \\
\hline $\mathrm{T} \times \mathrm{D}$ & & 0.353 & 0.863 & 0.863 & 0.654 & 0.666 & 0.522 \\
\hline
\end{tabular}

${ }^{2}$ Total number seasonal applications were ten and seven for treatments applied every 14 and $21 \mathrm{~d}$, respectively.

${ }^{y}$ Mean separation within columns by a Fisher's protected LSD test, $P=0.05$.

study, WIC and STC did not change the bulk soil volume by creating narrow channels. Channels were significant for infiltration and salt leaching, but long-term changes in the bulk soil volume would probably require modifications in soil texture.

The WIC and STC treatments did not significantly affect overall root weight density in the $0-$ to $7.5-\mathrm{cm}$ and $7.5-$ to $15.0-\mathrm{cm}$ depths. Murphy and Rieke (1994) reported that WIC did not affect total root weight or root weight density in the 0 - to 200-mm depth. However, HTC significantly reduced total root weight and root weight density, especially in the 0 - to 50-mm depth.

\section{Conclusions}

To compensate for stresses associated with summer decline of annual bluegrass putting greens, good soil physical and hydraulic properties must be maintained to allow sufficient water infiltration, salt leaching, and good aeration.

Summer treatment with WIC and STC significantly increased field infiltration rates of water and reduced soil salinity for an in-use practice putting green. Such treatments can help reduce multiple summer stresses in man- aging annual bluegrass putting greens in southern California. The WIC in the raised position did not differ significantly from STC, although it had greater field infiltration rates of water on all dates. The treatments did not significantly affect bulk density or total and air-filled porosity. Air-filled porosity and ODR measurements indicated that soil aeration at this site was sufficient for plant growth.

\section{Literature Cited}

Cassel, D.K. and D.R. Nielsen. 1986. Field capacity and available water capacity, p. 901-926. In: A Klute (ed.). Methods of soil analysis. Part 1. Physical and mineralogical methods. Agron. Monogr. No. 9. 2nd ed. Amer. Soc. Agron. and Soil Sci. Soc. Amer. Madison, Wis.

Carrow, R.N. and R.R. Duncan. 1998. Salt-affected turfgrass sites: Assessment and management. Ann Arbor Press, Chelsea, Mich.

Carrow, R.N. and A.M. Petrovic. 1992. Effects of traffic on turfgrasses, p. 285-330. In: D.V. Waddington, R.N. Carrow, and R.C. Shearman (eds.). Turfgrass. Agron. Monogr. No. 32. Amer. Soc. Agron., Crop. Sci. Soc. Amer. and Soil Sci. Soc. Amer. Madison Wis.

Carrow, R.N. and G. Wiecko. 1989. Soil compaction and wear stresses on turfgrasses: Future research directions, p. 37-42. In: H. Takatoh (ed.). Proc. 6th Intl. Turfgrass Res. Conf., Tokyo, July 1989. Jpn. Soc. Turfgrass Sci.
GLA Agricultural Electronics. 1995. GLA M33.1 Instant EC salinity tester user's manual. San Luis Obispo, Calif.

Klute, A. 1986. Water retention: Laboratory methods, p. 635-662. In: A. Klute (ed.). Methods of soil analysis. Part 1. Physical and mineralogical methods. Agron. Monogr. No. 9. 2nd ed. Amer. Soc. Agron. and Soil Sci. Soc. Amer. Madison, Wis.

Murphy, J.A. and P.E. Rieke. 1994. High pressure water injection and core cultivation of a compacted putting green. Agron. J. 86:719-724.

Phene, C.J. 1986. Oxygen electrode measurement, p. 1137-1159. In: A. Klute (ed.). Methods of soil analysis. Part 1. Physical and mineralogical methods. Agron. Monogr. No. 9. 2nd ed. Amer. Soc. Agron. and Soil Sci. Soc. Amer. Madison, Wis.

Rieke, P.E. and J.A. Murphy. 1989. Advances in turf cultivation, p. 49-54. In: H. Takatoh (ed.). Proc. 6th Intl. Turfgrass Res. Conf., Tokyo, July 1989. Jpn. Soc. Turfgrass Sci.

Shapiro, S.S. and M.B. Wilk. 1965. An analysis of variance test for normality (complete samples). Biometrika 52:591-611.

Stolzy, L.H. and J. Letey. 1964. Measurement of oxygen diffusion rates with the platinum microelectrode. III. Correlation of plant response to soil oxygen diffusion rates. Hilgardia 35:567-576.

Wu, L., L. Pan, M.J. Roberson, and P.J. Shouse. 1997. Numerical evaluation of ring-infiltrometers under various soil conditions. Soil Sci. 162:771777. 